\title{
New fossil remains of the commensal barnacle Cryptolepas rhachianecti provide evidence of gray whales in the prehistoric South Pacific
}

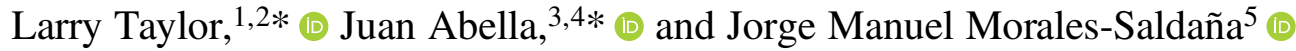 \\ ${ }^{1}$ Department of Integrative Biology and University of California Museum of Paleontology, University of California, Berkeley, Berkeley, CA \\ 94720, USA <larry.taylor@berkeley.edu> \\ ${ }^{2}$ Helena College, University of Montana, Helena, MT 59601, USA <larry.taylor@ helenacollege.edu> \\ ${ }^{3}$ Institut Català de Paleontologia Miquel Crusafont, Edifici Institut de Ciència i Tecnologia Ambientals - Institut Català de Paleontologia \\ (ICTA-ICP), Universitat Autònoma de Barcelona, Barcelona, Spain < juan.abella@icp.cat> \\ ${ }^{4}$ Instituto Nacional de Biodiversidad, Quito, Ecuador \\ ${ }^{5}$ Smithsonian Tropical Research Institute, Balboa, Republic of Panama <jorgemorales0709@gmail.com>
}

\begin{abstract}
We report the finding of two partial specimens of Cryptolepas rhachianecti (Cirripedia, Coronulidae), a coronulid barnacle known only to inhabit the skin of gray whales (Eschrichtius robustus), in Pleistocene-aged sediments from the Canoa Basin, Ecuador. While the historical range of gray whales includes the North Pacific and North Atlantic, to our knowledge this is the first inferred evidence of a gray whale population having resided within the South Pacific. We describe the two Cryptolepas rhachianecti fossils, use isotopic analysis to investigate evidence of migration in their host whales, and discuss their implications for our understanding of gray whale evolutionary history.
\end{abstract}

\section{Introduction}

Coronuloidea consists of a superfamily of commensal barnacles adapted to live on a remarkable variety of organisms, including manatees, crabs, mollusks, sea snakes, sea turtles, and cetaceans (Hayashi, 2013). The whale-living barnacles, or coronulids (family Coronulidae), are the most recently derived lineage, having diverged from the other commensal barnacles within the past five million years (Hayashi et al., 2013). This timing coincides with the onset of gigantism in baleen whales (Slater et al., 2017), and most coronulids make their home on the modern giants, although some species are occasionally seen on delphinids (Seilacher, 2005; Hayashi, 2012).

As a group, the coronulids are relatively abundant throughout the modern oceans. The most abundant coronulid species in the oceans today is Coronula diadema (Linnaeus, 1767), which lives attached to the skin of humpback whales (Megaptera novaeangliae Borowski, 1781). Where whale barnacle fossils are found, they belong nearly exclusively to the genus Coronula (Fleming, 1959; Zullo, 1969; Beu, 1971; Buckeridge, 1983; Bianucci et al., 2006a, b; Dominici et al., 2011; Collareta et al., 2016; Taylor et al., 2019). The genus Cryptolepas is represented by a single extant species, Cryptolepas rhachianecti, which is a host-specific inhabitant of the skin of gray whales (Eschrichtius robustus Lilljeborg, 1861) (Newman and Ross, 1976; Newman and Abbott, 1980; Seilacher, 2005; Bradford et al., 2011; Hayashi, 2012; Swartz, 2018). Like its host,

*Corresponding author.
C. rhachianecti previously has been known only from the Northern Hemisphere, both in the present day and within the fossil record. While fossil whale barnacles usually exist in small numbers wherever they are found, an exception to this general rule is the Canoa Basin of Ecuador, where dozens of coronulid fossils have been collected, previously all assigned to the genus Coronula (Bianucci et al., 2006a, b).

Here we report finding two partial shells of the gray whale barnacle Cryptolepas rhachianecti in Pleistocene-aged deposits from the Canoa Basin, Ecuador. To our knowledge, these are the oldest known fossil specimens of Cryptolepas, the first occurrences of the genus in the Southern Hemisphere, and the first evidence of a gray whale population regularly living in or migrating through the southern Pacific Ocean.

\section{Geological setting}

Specimens were collected in Pleistocene-aged sediments of the Canoa Basin in the Cabo San Lorenzo area of the Manabi Province, Ecuador $\left(1.1821^{\circ} \mathrm{S}, 80.8622^{\circ} \mathrm{W}\right)$. During the PlioPleistocene, the Cabo San Lorenzo area was an uplifting island separated from mainland Ecuador by a shallow, narrow strait. Continued uplift eventually connected this island to mainland Ecuador via a land bridge. Glacial-interglacial oscillations caused the shoreline to advance and retreat multiple times, extending west of present-day La Plata Island during glacial periods, when sea level was lower (Di Celma et al., 2002, 2005; Cantalamessa and Di Celma, 2004). During warmer interglacials, rising sea levels resulted in the shoreline retreating eastward to create a southwesterly facing coastal embayment, the 

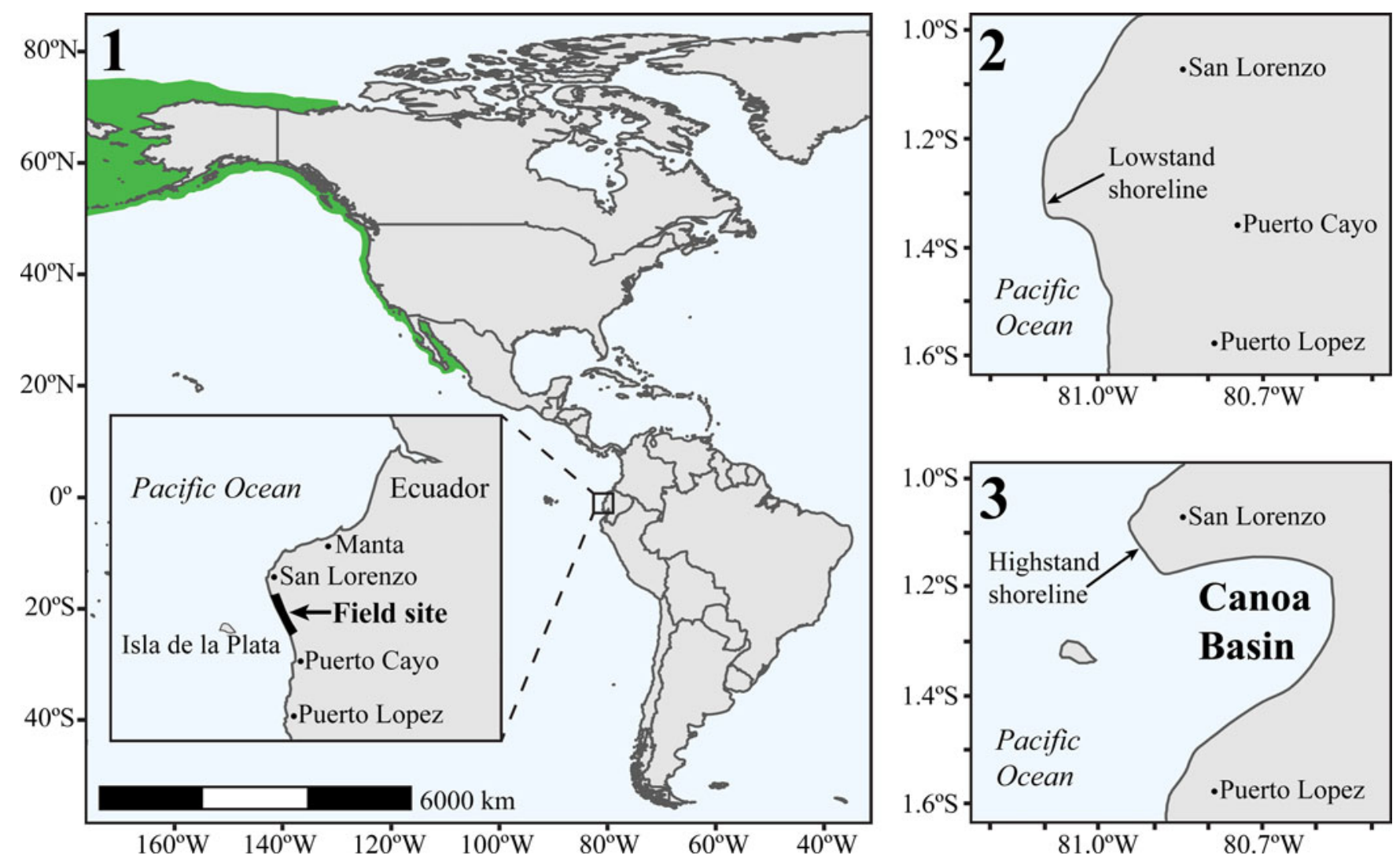

Figure 1. (1) A map showing the location of the Canoa Basin sediments in relation to the range of modern-day gray whales, with inset showing greater detail of the region surrounding the field site. (2) During glacial lowstands, the Canoa coastline extended west past present-day Isla de la Plata. (3) During past interglacial highstands, the coastline moved east, creating a small coastal embayment, the Canoa Basin.

Canoa Basin (Fig. 1). Over time, the basin has been progressively filled by $\sim 120 \mathrm{~m}$ of cyclically stacked shallow marine strata (Di Celma et al., 2002, 2005).

Stratigraphic, sedimentological, paleoecological, and taphonomic studies of the entire succession indicate it is composed of a series of glacio-eustatically driven parasequences capturing recurring periods of rising and falling sea levels, exposed along $\sim 10 \mathrm{~km}$ of coastline between Punta Canoa and Rio Callejón (Di Celma et al., 2002, 2005). The succession has been divided into the lower Canoa and upper Tablazo formations, with the Canoa Formation being further divided by an angular unconformity (Sheppard, 1930; Pilsbry and Olsson, 1941; Marchant, 1961; Savoyat, 1971; Baldock, 1982; Tsuchi et al., 1988; Whittaker, 1988; Di Celma et al., 2005). Older sediments in the basin have yielded Oligo-Miocene fossils, and the Miocene-aged Tosagua Formation lies just below the lower Canoa (Cadena et al., 2018). The lower Canoa rests unconformably atop the Tosagua, and is composed of fine-grained, bluishgray, silty to sandy shales (Di Celma et al., 2005). Above, the upper Canoa consists of gray-brown silts to sands, overlain by the brown sands of the Tablazo Formation. Sediments in both formations are rich in fossils (bivalves, gastropods, echinoids, crustaceans, corals, and occasional vertebrate remains) (Bianucci et al., 2006a; Flores et al., 2018).

The lower Canoa consists of four depositional sequences formed under the control of $40 \mathrm{kyr}$-long sea level fluctuations (Di Celma et al., 2002, 2005; Cantalamessa and Di Celma,
2004). Each sequence is bound below by an erosional surface, above which lies a basal hiatal shell bed followed by several meters of sparsely fossiliferous sediment (Di Celma et al., 2005). While the lowermost shell bed is quite taxa-rich and densely packed, whale barnacles are rare in the lowest two sequences and become more abundant thereafter. The upper Canoa and Tablazo formations are interpreted to be a continuous sedimentary record of two and six depositional sequences created under the control of $100 \mathrm{kyr}$-long sea level fluctuations (Di Celma et al., 2005). Shell beds are found basally and mid-cycle, separated by sparsely fossiliferous siliciclastics, and exhibit within-habitat time averaging (Bianucci et al., 2006a). The Tablazo Formation was described and is best known from the Santa Elena Province ( $\sim 120 \mathrm{~km}$ to the south of this site), and has yielded mostly continental fossils (Hoffstetter, 1952; Edmund, 1965; Ficcarelli et al., 2003; Lindsey and Lopez, 2015; Cadena et al., 2017), but also marine remains (Edmund, 1965; Flores, 2018; Flores et al., 2020).

The Canoa and Tablazo formations previously have yielded dozens of whale barnacles belonging to the species Coronula diadema, which lives on the skin of humpback whales, leading to the conclusion that the Canoa Basin was visited by migrating whales in the Pleistocene (Bianucci et al., 2006a, b).

\section{Materials and methods}

Fossils were collected in September 2018 from sediments of the upper Canoa Formation in the Canoa Basin, Ecuador, 
coordinates $1.1821^{\circ} \mathrm{S}, 80.8622^{\circ} \mathrm{W}$. For isotopic analysis, a small Dremel handheld drill was used to collect calcite samples of 50 100 micrograms from along the primary (vertical) growth axis of the shell. Samples were analyzed at the Center for Stable Isotope Biogeochemistry at the University of California, Berkeley with a GV IsoPrime mass spectrometer with Dual-Inlet and MultiCarb systems. Several replicates of one international standard NBS19 and two lab standards $\mathrm{CaCO} 3-\mathrm{I}$ and II were measured along with every run of samples. Overall external analytical precision is $\pm 0.07 \%$ o for $\delta^{18} \mathrm{O}$ and $\pm 0.05 \%$ o for $\delta^{13} \mathrm{C}$.

Barnacle calcite $\delta^{18} \mathrm{O}$ is determined by both the temperature and $\delta^{18} \mathrm{O}$ of the seawater in which it forms, as described by the balanomorph-barnacle paleotemperature equation of Killingley and Newman (1982):

$$
\mathrm{t}\left({ }^{\circ} \mathrm{C}\right)=22.14-4.37(\delta \mathrm{C}-\delta \mathrm{W})+0.07(\delta \mathrm{C}-\delta \mathrm{W})^{2}
$$

where $\delta \mathrm{C}$ denotes barnacle calcite $\delta^{18} \mathrm{O}$ and $\delta \mathrm{W}$ denotes seawater $\delta^{18} \mathrm{O}$. Because of latitudinal differences in the whale's feeding and breeding regions, the barnacle experiences the coldest waters in the summer feeding season. Although this will also generally correspond with the lowest seawater $\delta^{18} \mathrm{O}$, the temperature-dependent fractionation in barnacles (and other calcifying organisms) generates an enriched shell calcite $\delta^{18} \mathrm{O}$ in cold temperatures and a depleted $\delta^{18} \mathrm{O}$ in warm temperatures.

Repositories and institutional abbreviations.-Specimens collected and described in this study are deposited at the University of California Museum of Paleontology (UCMP), Berkeley, California, and in the California Academy of Sciences (CAS), San Francisco, California.

\section{Systematic paleontology}

Class Maxillopoda Dahl, 1956

Subclass Cirripedia Burmeister, 1834

Superorder Thoracica Darwin, 1854

Order Sessilia Lamarck, 1818

Suborder Balanomorpha Pilsbry, 1916

Superfamily Coronuloidea Leach, 1817

Family Coronulidae Leach, 1817

Genus Cryptolepas Dall, 1872

Type species.-Cryptolepas rhachianecti Dall, 1872, from beached whale, Monterey, CA, U.S.A., by original designation.

Other species.-Cryptolepas murata Zullo, 1961, from Pleistocene deposits of San Quentin Bay, CA, U.S.A., by original designation.

Cryptolepas rhachianecti Dall, 1872 Figure 2

Holotype.-Shell collected from beached whale, Monterey, CA, U.S.A., (Dall, 1872, p. 300).

Description.-Specimen UCMP 116131 is a single compartment, with the radial lamellae mostly missing.
Specimen UCMP 116132 is also represented by a single compartment, but is more complete, with many of the radial lamellae still intact (Fig. 2). Taken together, several characters identify the specimens as Cryptolepas rhachianecti; these include a transversely grooved sheath, the presence of four lamellar folds plus two half (sutural) folds on each compartment, irregularly branching radial lamellae where many branches fail to reach the periphery, and the absence of terminal flanges uniting the radial lamellae into a solid outer wall (Pilsbry, 1916; Davis, 1972). Transverse grooving of the sheath is present in both UCMP 116131 and UCMP 116132. The eroded lamellar folds are clear on the outward-facing walls of UCMP 116131. In UCMP 116132, many of the lamellar folds are well-preserved and display the species' characteristic irregular branching pattern, the failure of several of these branches to reach the periphery, and the absence of the wall-forming terminal flanges found in some other coronulids (Fig. 2). UCMP 116131 bears a strong resemblance to a (sub)fossil Cryptolepas rhachianecti specimen from the Netherlands reported by Bosselaers and Collareta (2016), and closely resembles a worn shell depicted by Pilsbry (1916, pl. 66, fig. 2).

Remarks.-Specimens UCMP 116131 and UCMP 116132 were both collected from the upper Canoa Formation. The features described above distinguish Cryptolepas from Coronula - a coronulid found in much greater abundance in the Canoa deposits. Coronula has an ungrooved sheath, fewer lamellar folds, fewer branches arising from the folds (all of which reach the periphery), and a solid outer wall formed by the uniting of T-shaped terminal flanges of the folds.

While fossils of the genus Cryptolepas are sparse, two species are now recognized in the fossil record. The first is $C$. rhachianecti, reported here and as a (sub)fossil from the Netherlands (Bosselaers and Collareta, 2016). The second is C. murata, reported by Zullo (1961) from late Pleistocene deposits of California. Cryptolepas traditionally has been suggested to have derived from the lineage that includes Coronula and Cetopirus, with the major differences in shell morphology seen in Cryptolepas interpreted as degenerative changes related to the more embedded, protected station of the shell in the host's skin (Pilsbry, 1916; Monroe, 1981). A primary feature distinguishing Cryptolepas rhachianecti from Coronula and Cetopirus is the absence of a complete outer wall to the shell, which in the latter two genera is formed by the merging of T-shaped flanges at the ends of the lamellar folds and which serves to create coring chambers that envelop prongs of the host's skin. Zullo (1961) interpreted C. murata as being an intermediate form, possessing many of the distinguishing features of C. rhachianecti while retaining an outer wall to the shell (Zullo, 1961, 1969). Bosselaers and Collareta (2016) have questioned whether Cryptolepas murata should be reassigned to the genus Cetopirus, but the rarity of Cryptolepas fossils makes answering that question difficult. While $C$. murata shares with Cetopirus an outer wall formed by terminal flanges of the lamellar folds, it also shares with $C$. rhachianecti a grooved sheath, less symmetrical internal branching of the lamellar folds, and the presence of internal branches that fail to reach the periphery of the shell (Fig. 2). 


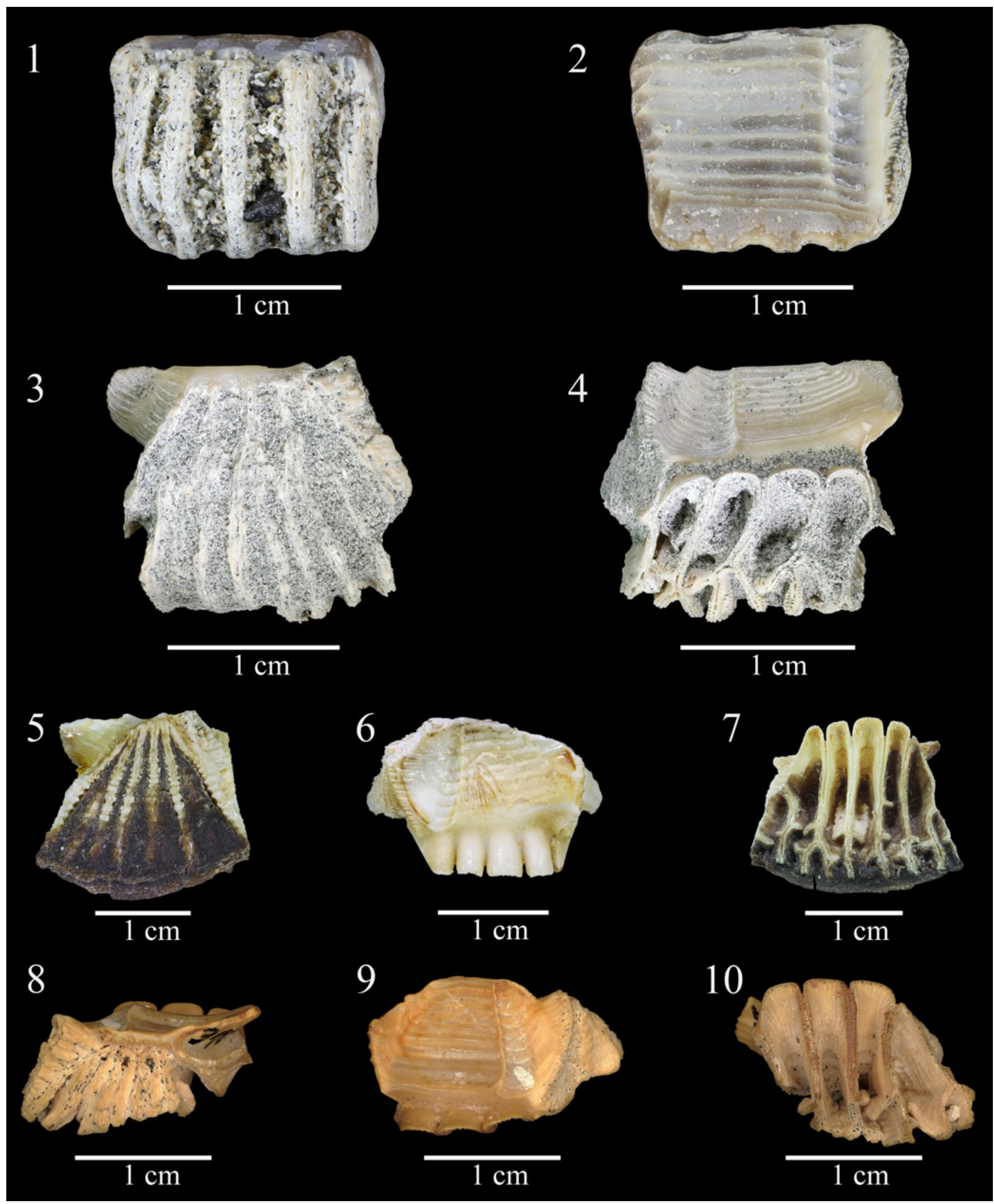

Figure 2. Fossil Cryptolepas rhachianecti shells UCMP $116131(\mathbf{1}, \mathbf{2})$ and UCMP $116132(\mathbf{3}, \mathbf{4})$ from Pleistocene sediments of the Canoa Basin, Ecuador, alongside modern C. rhachianecti shell UCMP 34678 (5-7) and fossil C. murata shell UCMP 34677 (8-10). Fragile folds of shell are supported by whale skin in life (dark material seen in 5, 7) and will easily crumble when dislodged; the folds of UCMP 116132 survived by support from fine-grained sediment $(\mathbf{3}, \mathbf{4})$. The grooved sheath

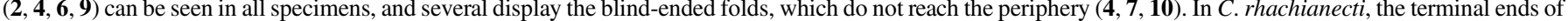
the primary folds do not connect to neighboring folds $(\mathbf{4}, \mathbf{7})$, while in C. murata, the terminal ends of the folds fuse to form a rudimentary outer wall $(\mathbf{8}, \mathbf{1 0})$, similar to that of the genus Coronula. 


\section{Results}

Oxygen isotope ratios of coronulid shells have been shown to record the movements of their host whales (Killingley, 1980; Collaretta et al., 2018; Taylor et al., 2019). Isotopic analysis of fossil Cryptolepas rhachianecti shells UCMP 116131 and UCMP 116132 revealed $\delta^{18} \mathrm{O}$ ranges of $1.93 \%$ and $2.14 \%$ (Fig. 3), which is less than the 2.61-3.28\% range measured in a modern-day $C$. rhachianecti shells of similar size (Fig. 3; Taylor et al., 2019, fig. S2). The fossils also have lower $\delta^{18} \mathrm{O}$ maxima than their modern counterparts. Fossil shell $\delta^{13} \mathrm{C}$ is likewise depleted relative to that of modern shells, and $\delta^{13} \mathrm{C}$ is only loosely correlated with $\delta^{18} \mathrm{O}$ (Fig. 3; Taylor et al., 2019, fig. S2).

\section{Discussion}

To our knowledge, these specimens represent the oldest known occurrence of Cryptolepas rhachianecti, and the first report of the species in the southern hemisphere. The oldest previously reported specimen of $C$. rhachianecti is a single compartment from late Quaternary deposits in the Netherlands (Bosselaers and Collareta, 2016). The gray whale lineage has a geological and historical presence in much of the North Atlantic, and it is reasonable to expect that $C$. rhachianecti also once ranged throughout the North Atlantic as well (Bisconti and Varola, 2006; Noakes et al., 2013; Alter et al., 2015; Bosselaers and Collareta, 2016; Hufthammer et al., 2018; Rodrigues et al., 2018). Overharvesting led to the final collapse of this population by sometime in the $18^{\text {th }}$ century, however, and today $C$. rhachia$n e c t i$ is found only in the North Pacific, where it is a host-specific symbiont of the gray whale (Newman and Ross, 1976; Newman and Abbott, 1980; Scarff, 1986; Bradford et al., 2011; Hayashi, 2012). Modern gray whales live in two distinct populations in the western and eastern North Pacific, although some interchange between these populations does occur (LeDuc et al., 2002; Cooke et al., 2007; IWC, 2011). While the fossil record clearly attests to the presence of the gray whale lineage in the North Pacific, there are no historical or fossil records of gray whale populations living in the equatorial Pacific or southern hemisphere (Tsai et al., 2014; Tsai and Boessenecker, 2015; Kimura et al., 2018).

Besides the Netherlands specimen, no other fossils of C. rhachianecti are known, most likely due to the fragile nature of the shell. Due to this fragility, much of the fine structure of UCMP 116132 was damaged during isotopic sampling (images in Fig. 2 were taken prior to sampling). Whereas other whale barnacles extrude far above the host's skin and consequently are constructed robustly, $C$. rhachianecti lives deeply buried in the skin of gray whales, with the shell being largely supported by the skin of the host interweaving between the radial lamellae (Fig. 2). This embedded, low-profile lifestyle of $C$. rhachianecti may be related to the suction-feeding habit of gray whales, which causes the whales to rub their skin on the seafloor. If $C$. rhachianecti shells protruded much more above the skin, they would risk being dislodged or destroyed via abrasion.

The fragility of $C$. rhachianecti shells and their resulting scarcity in the fossil record suggests that the barnacles' host whales must have been a common visitor of the ancient Canoa Basin, considering we found two specimens in only three days of fieldwork. Whale barnacles are thought to be shed mostly
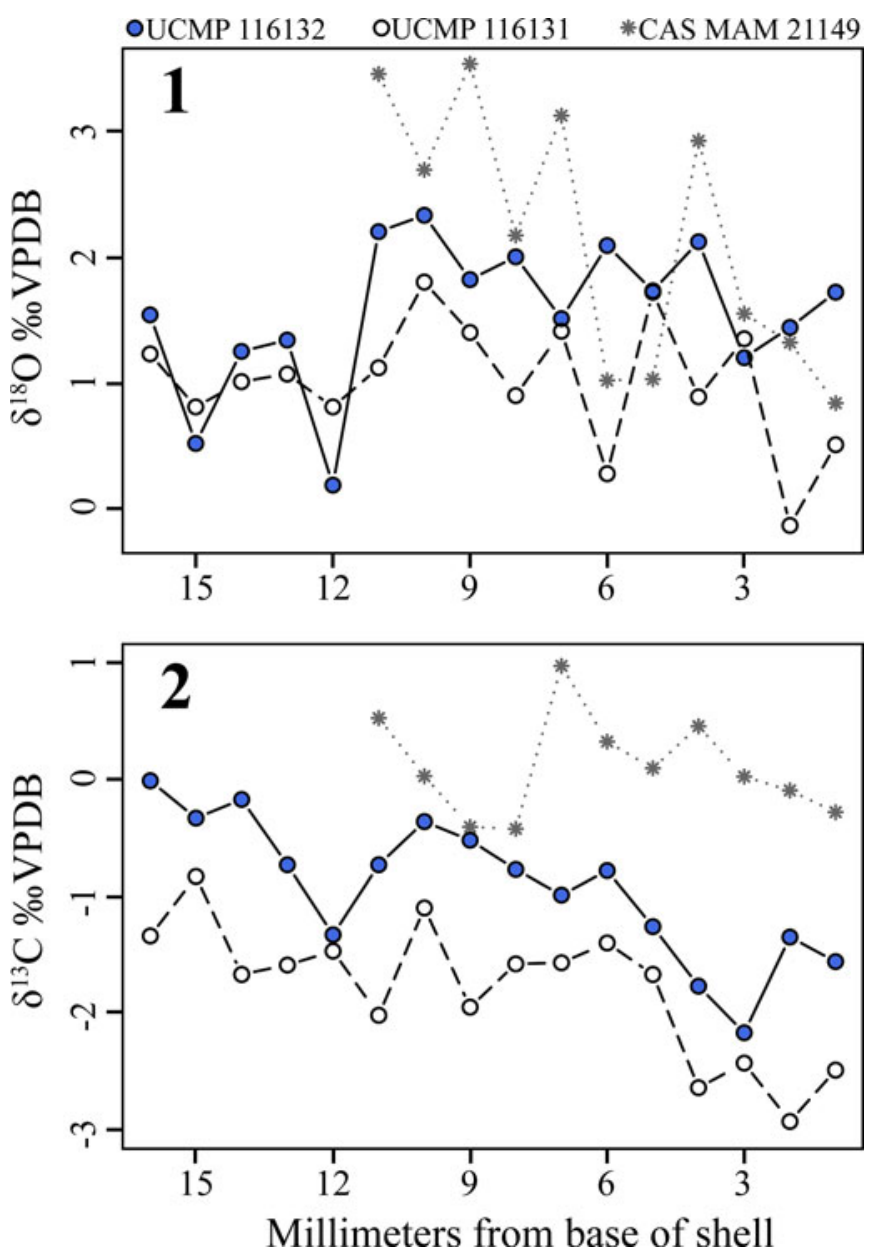

Figure 3. $\delta^{18} \mathrm{O}(\mathbf{1})$ and $\delta^{13} \mathrm{C}(2)$ profiles collected from along the primary growth axis of UCMP 116131, UCMP 116132, and CAS MAM 21149. CAS MAM 21149 is a modern C. rhachianecti shell collected from a gray whale that beached in northern California, likely while migrating south from its summer feeding areas. $\delta^{18} \mathrm{O}$ of barnacle shells is determined by the temperature and isotopic composition of the seawater in which the barnacle was located during each growth interval. Shell $\delta^{13} \mathrm{C}$ is affected by several factors and is best interpreted in conjunction with $\delta^{18} \mathrm{O}$, where positive correlations may indicate changes in temperature or salinity, while depleted $\delta^{13} \mathrm{C}$ coupled with enriched $\delta^{18} \mathrm{O}$ may be a signal of upwelling. Analytical precision is $\pm 0.07 \%$ o for $\delta^{18} \mathrm{O}$ and $\pm 0.05 \%$ or $\delta^{13} \mathrm{C}$.

while host whales are in their winter breeding areas, and accumulations of fossil whale barnacle shells have been interpreted as representing ancient whale breeding areas (Monroe, 1981; Bianucci et al., 2006a, b; Taylor et al., 2019). Our finding of Cryptolepas rhachianecti fossils raises the possibility that a Pleistocene gray whale population used the Canoa Basin as a winter breeding area.

Extant gray whales in the eastern North Pacific spend their summer months feeding in cold, poleward waters, primarily in the Bering and Chukchi Seas, before migrating southward to warm, shallow, and sheltered waters along the coast of Baja California Sur to breed and raise their calves (Swartz et al., 2006; Mate et al., 2015). The Pleistocene Canoa Basin would have offered conditions similar to the lagoons and bays where modern gray whales overwinter, and the large number of Coronula diadema fossils found in the region suggests that the region at least served as an ancient breeding area for humpback whales (Bianucci et al., 2006a). While humpback and gray whales do 
not typically winter together, they do sometimes seek out similar water depths and temperatures (Martins et al., 2000), and wintering populations of both species can be found only a few miles apart along the coast of present-day Baja California.

If a Pleistocene gray whale population once inhabited the South Pacific, it has not survived to the present day. Humpback whales, on the other hand, still breed off the modern Ecuadorian coast. Compared to humpbacks, gray whales are less numerous, less ubiquitous, and more selective about areas where they will feed or breed. These differences may have made prehistoric gray whales comparatively rarer and more sensitive to change. While they are capable of generalist filter feeding like the other baleen whales, gray whales primarily prey on shallow, benthic invertebrate communities via suction feeding. This feeding habitat was greatly reduced during glacial maxima, however, reducing carrying capacity for the species (Pyenson and Lindberg, 2011). It is plausible that one of these disruptions could have winnowed a southern population beyond recovery, and that an intolerance for crossing warm equatorial waters coupled with the fidelity of whale mothers to their natal lagoons has kept the species from recolonizing these areas in the modern day (Lindberg, 1991; Goerlitz et al., 2003; IWC, 2011).

At least in the Canoa region, however, a primary cause of the loss of gray whales must have been the continual uplift of the Ecuador coast, which has eliminated the shallow embayments suitable for gray whale breeding. Gray whales only raise calves in sheltered lagoons and embayments, typically in waters of $10 \mathrm{~m}$ depth or less (Gardner and Chavez-Rosales, 2000; Goerlitz et al., 2003; IWC, 2011). While previous periods of high sea level would have created such a suitable breeding habitat within the Canoa Basin, uplift of the Ecuadorian coast has resulted in the modern Canoa coast being dominated by cliffs, while Andean uplift has further eliminated shallow embayments along the South American coast (Lindberg, 1991). Humpback whales, in contrast, will breed in a wider variety of water depths, and so may have been undisturbed by this loss of shallow habitat (Felix and Botero-Acosta, 2011; Pack et al., 2017).

An alternative explanation is that $C$. rhachianecti once commonly occurred on a different host whale species. However, there is little to support this hypothesis. Settlement of coronulid larvae seems to be initiated by chemical cues from the preferred host's skin (Nogata and Matsumura, 2005), while contact with other hosts initiates an immune response capable of shedding a barnacle (Ridgeway et al., 1997). Consequently, the most parsimonious explanation for the occurrence of $C$. rhachianecti fossils within the deposits is the prior presence of gray whales in the area.

The $\delta^{18} \mathrm{O}$ range of the Canoa Basin fossils is smaller than that collected from modern $C$. rhachianecti specimens, which may reflect the fragmentary nature of the shells, or it may reflect real differences in the migratory extent of the host whales as compared to their modern counterparts. If there was once a population of gray whales visiting the coast of Ecuador, then those whales have no directly comparable modern counterpart, but some insight may come from looking at the behavior of humpback whales that breed off the modern Ecuador coast (Sheidat et al., 2000; Felix and Botero-Acosta, 2011). These modern humpbacks are known to migrate to feeding areas along the coast of Chile, within the Magellan Strait, and along the Antarctic Peninsula (Gibbons et al., 2003; Acevedo et al.,
2007; Capella et al., 2008; Felix and Olavarria, 2012; HuckeGaete et al., 2013). It is known that small numbers of modern gray whales do not migrate (Pyenson and Lindberg, 2011), but the $\delta^{18} \mathrm{O}$ ranges of these fossils are difficult to explain via annual variation in the immediate area, suggesting that the whales did migrate to some extent. The $\delta^{18} \mathrm{O}$ maxima are less enriched than would be expected if the host whales were traveling to Antarctica, but the $\delta^{18} \mathrm{O}$ ranges are similar to those of some barnacles collected from modern, migrating humpback whales (Taylor et al., 2019). It is plausible these ancient whales may have migrated to the Chilean coast, as some modern humpbacks do (Gibbons et al., 2003; Acevedo et al., 2007; Capella et al., 2008; Felix and Olavarria, 2012; Hucke-Gaete et al., 2013), but they also may have migrated to any number of unknown ancient feeding grounds.

Interpreting shell $\delta^{13} \mathrm{C}$ is less straight forward because $\delta^{13} \mathrm{C}$ may be affected by the incorporation of metabolic carbon, kinetic disequilibrium effects, temperature-dependent fractionation, and the effects of upwelling or freshwater input on $\delta^{13} \mathrm{C}$ of dissolved inorganic carbon. Interpretation of shell $\delta^{13} \mathrm{C}$ is best done in conjunction with corresponding shell $\delta^{18} \mathrm{O}$, where depletion of both $\delta^{13} \mathrm{C}$ and $\delta^{18} \mathrm{O}$ may be a signal of freshwater input, and where depletion of $\delta^{13} \mathrm{C}$ corresponding to enriched $\delta^{18} \mathrm{O}$ may be a signal of upwelling (Killingley and Berger, 1979; Killingley and Lutcavage, 1983; Bemis and Geary, 1996; Sadler et al., 2012). There is some indication of depletion of $\delta^{13} \mathrm{C}$ where $\delta^{18} \mathrm{O}$ is most enriched in modern $C$. rhachianecti shells (Fig. 3; Taylor et al., 2019, fig. S2), but in both modern and fossil shells $\delta^{13} \mathrm{C}$ and $\delta^{18} \mathrm{O}$ are either not correlated or show a slight positive correlation over the majority of the captured signal, indicating that freshwater input and other factors may be exerting a strong influence on shell $\delta^{13} \mathrm{C}$.

With only a handful of Cryptolepas fossils known, our finding of $C$. rhachianecti fossils in the Canoa Basin makes the region a promising area for further study. Collecting and isotopically analyzing more $C$. rhachianecti fossils from the Canoa Basin may offer more insight into the behavior of this prehistoric whale population.

\section{Acknowledgments}

Specimens were collected using excavation permit number M-JA-2018-82. Thank you to F. Flores and X. Guncay, our undergraduate research assistants during field work. We also thank D. Strauss and S. Kahanamoku of the UCMP for their work in photographing the specimens. We thank J. Jijón (Instituto Nacional de Patrimonio Cultural, Ecuador) for his support and help before, during, and after fieldwork. This study was supported by the Generalitat de Catalunya (CERCA Programme, and Beatriu de Pinós contract 2017 BP 00223 from AGAUR to JA), by the Geological Society of America, by the UC Berkeley Department of Integrative Biology, by the University of California Museum of Paleontology, by the American Society of Naturalists, and by the Paleontological Society.

\section{References}

Acevedo, J., Rasmussen, K., Felix, F., Castro, C., Llano, et al., 2007, Migratory destinations of humpback whales from the Magellan Strait feeding ground, southeast Pacific: Marine Mammal Science, v. 23, p. 453-463. 
Alter, S.E., Meyer, M., Post, K., Czechowski, P., Gravlund, P., Gaines, C., Rosenbaum, H.C., Kaschner, K., Turvey, S.T., van der Plicht, J., Shapiro, B., and Hofreiter, M., 2015, Climate impacts on transocean dispersal and habitat in gray whales from the Pleistocene to 2100: Molecular Ecology, v. 24 , p. $1510-1522$.

Baldock, J.W., 1982, Geología del Ecuador: Boletín de la explicación del mapa geológico nacional de la República del Ecuador, Dirección de Investigación Geológico-Minera.

Bemis, B.E., and Geary, D.H., 1996, The usefulness of bivalve stable isotope profiles as environmental indicators: data from the eastern Pacific Ocean and the southern Caribbean Sea: Palaios, v. 11, p. 328-339.

Beu, A.G., 1971, Further fossil whale barnacles from New Zealand: New Zealand Journal of Geology and Geophysics, v. 14, p. 898-904.

Bianucci, G., Di Celma, C., Landini, W., and Buckeridge, J., 2006a, Palaeoecology and taphonomy of an extraordinary whale barnacle accumulation from the Plio-Pleistocene of Ecuador: Palaeogeography, Palaeoclimatology, Palaeoecology, v. 242, p. 326-342.

Bianucci, G., Landini, W., and Buckeridge, J., 2006b, Whale barnacles and Neogene cetacean migration routes: New Zealand Journal of Geology and Geophysics, v. 49, p. 115-120.

Bisconti, M., and Varola, A., 2006, The oldest eschrichtiid mysticete and a new morphological diagnosis of Eschrichtiidae (gray whales): Rivista Italiana di Paleontologia e Stratigrafia, v. 112, p. 447-457.

Borowski, G.H., 1781, Gemeinnüzzige Naturschichte des Tierreichs: Berlin and Stralsund, G.L. Lange, v. 2, 196 p.

Bosselaers, M., and Collareta, A., 2016, The whale barnacle Cryptolepas rhachianecti (Cirripedia: Coronulidae), a phoront of the grey whale Eschrichtius robustus (Cetacea: Eschrichtiidae) from a sandy beach in The Netherlands: Zootaxa, v. 4145, p. 331-338.

Bradford, A.L., Weller, D.W., Burdin, A.M. and Brownell, R.L., Jr., 2011, Using barnacle and pigmentation characteristics to identify gray whale calves on their feeding grounds: Marine Mammal Science, v. 27, p. 644-651.

Buckeridge, J.S., 1983, Fossil barnacles (Cirripedia: Thoracica) of New Zealand and Australia: New Zealand Geology Survey Paleontological Bulletin, v. 50, p. $1-151$.

Burmeister, H., 1834, Beiträge zur Naturgeschichte der Rankenfüser (Cirripedia): Berlin, G. Reimer, 60 p.

Cadena, E., Abella, J., and Gregori, M., 2017, New findings of Pleistocene fossil turtles (Geoemydidae, Kinosternidae and Chelydridae) from Santa Elena Province, Ecuador: PeerJ, 5:e3215. https://doi.org/10.7717/peerj.3215.

Cadena, E., Abella, J., and Gregori, M., 2018, The first Oligocene sea turtle (Pan-Cheloniidae) record of South America: PeerJ, 6:e4554. https://doi. org/10.7717/peerj.4554.

Cantalamessa, G., and Di Celma, C., 2004, Origin and chronology of Pleistocene marine terraces of Isla de la Plata and of flat, gently dipping surfaces of the southern coast of Cabo San Lorenzo (Manabi, Ecuador): Journal of South American Earth Sciences, v. 16, p. 633-648.

Capella, J.J., Gibbons, J., Florez-Gonzalez, L., Llano, M., Valladres, C., Sabaj, V., and Vilina, Y.A., 2008, Migratory round-trip of individually identified humpback whales at the Strait of Magellan: clues on transit times and phylopatry to destinations: Revista Chilena de Historia Natural, v. 81, p. $547-560$.

Collareta, A., Margiotta, S., Varola, A., Catanzariti, R., Bosselaers, M., and Bianucci, G., 2016, A new whale barnacle from the early Pleistocene of Italy suggests an ancient right whale breeding ground in the Mediterranean: Comptes Rendus Palevol, v. 15, p. 473-481.

Collareta, A., Regattieri, E., Zanchetta, G., Lambert, O., Catanzariti, R., Bosselaers, M., Covelo, P., Varola, A., and Bianucci, G., 2018, New insights on ancient cetacean movement patterns from oxygen isotope analyses of a Mediterranean Pleistocene whale barnacle: Neues Jahrbuch für Geologie und Paläontologie-Abhandlungen, v. 288, p. 143-159.

Cooke, J.G., Weller, D.W., Bradford, A.L., Burdin, A.M., and Brownell, R.L., 2007, Population assessment of the western gray whales in 2007. Paper SC/59/BRG41 Presented to the International Whaling Commission Scientific Committee, Anchorage, AK: Publications, Agencies and Staff of the U.S. Department of Commerce, 69. https://digitalcommons.unl.edu/cgi/ viewcontent.cgi?article $=1068 \&$ context $=$ usdeptcommercepub.

Dahl, E., 1956, Some crustacean relationships, in Wingstrand, K.G., ed., Bertil Hanström, Zoological Papers in Honour of 65th Birthday: Lund, Zoological Institute, p. 138-147.

Dall, W.H., 1872, On the parasites of the cetaceans of the N.W. coast of America, with descriptions of new forms: Proceedings of the California Academy of Sciences v. 4, p. 299-301.

Darwin, C.R., 1854, A Monograph on the Sub-Class Cirripedia, with Figures of All Species: The Balanidae (or Sessile Cirripedia); the Verricidae, etc., etc., etc.: London, The Ray Society, $684 \mathrm{p}$.

Davis, C.W., 1972, Studies on the Barnacles Epizoic on Marine Vertebrates [MA thesis]: San Francisco, California State University, San Francisco, 60 p.
Di Celma, C., Ragaini, L., Cantalamessa, G., and Curzio, P., 2002, Shell concentrations as tools in characterizing sedimentary dynamics at sequencebounding unconformities: examples from the lower unit of the Canoa Formation (late Pliocene, Ecuador): Geobios, v. 35, p. 72-85.

Di Celma, C., Ragaini, L., Cantalamessa, G., and Landini, W., 2005, Basin physiography and tectonic influence on sequence architecture and stacking pattern: Pleistocene succession of the Canoa Basin (central Ecuador): Geological Society of America Bulletin, v. 117, p. 1226-1241.

Dominici, S., Bartalini, M., Benvenuti, M., and Balestra, B., 2011, Large kings with small crowns: a Mediterranean Pleistocene whale barnacle: Bollettino della Societa Paleontologica Italiana, v. 50, p. 95-101.

Edmund, A.G., 1965, A Late Pleistocene Fauna from the Santa Elena Peninsula, Ecuador: Toronto, Royal Ontario Museum, Life Sciences Division, $350 \mathrm{p}$.

Felix, F., and Botero-Acosta, N., 2011, Distribution and behaviour of humpback whale mother-calf pair during the breeding season off Ecuador: Marine Ecology Progress Series, v. 426, p. 277-287.

Felix, F., and Olavarria, C., 2012, Genetic diversity and population structure of humpback whales (Megaptera novaeangliae) from Ecuador based on mitochondrial DNA analyses: Journal of Cetacean Research and Management, v. 12 , p. $71-77$.

Ficcarelli, G., Coltorti, M., Moreno-Espinosa, M., Pieruccini, P.L., Rook, L., and Torre, D., 2003, A model for the Holocene extinction of the mammal megafauna in Ecuador: Journal of South American Earth Sciences, v. 15, p. 835-845.

Fleming, C.A., 1959, A Pliocene whale barnacle from Hawke's Bay, New Zealand: New Zealand Journal of Geology and Geophysics, v. 2, p. 242-247.

Flores, F.F., 2018, Estudio Poblacional del Tiburón Blanco (Carcharodon carcharias, Linnaeus, 1758), del Yacimiento Pleistoceno de Quebrada Tiburón (Atahualpa, Santa Elena, Ecuador) [Graduate thesis]: La Libertad, Ecuador, Universidad Estatal Península de Santa Elena, Ecuador.

Flores, F.F., Guncay, X., Carrillo-Briceño, J., Taylor, L.D., Morales, J., and Abella, J., 2018, Nuevos restos fósiles de peces condrictios y actinopterigios de la Formación Canoa y Tablazo (Cantón Montecristi, Manabí, Ecuador). XLII Jornados Nacionales de Biologia: Santa Elena, Ecuador, Universidad Estatal Península de Santa Elena.

Flores, F.F., Carrillo-Briceño, J.D., Guncay, X., and Abella, J., 2020, A great white shark (Carcharodon carcharias Linnaeus, 1758) paleopopulation from the Pleistocene of the Santa Elena Peninsula, Ecuador: 2nd Palaeontological Virtual Congress, p. 169. https://www.uv.es/palaeovc/Documentos $\% 20 / 2$ nd $\% 20$ PVC/2nd_PVC_Book_of_Abstracts.pdf.

Gardner, S.C., and Chavez-Rosales, S., 2000, Changes in the relative abundance and distribution of gray whales (Eschrichtius robustus) in Magdalena Bay, Mexico during and El Nino event. Marine Mammal Science, v. 16, p. $728-738$.

Gibbons, J., Capela, J.J., and Valladares, C., 2003, Rediscovery of a humpback whale (Megaptera novaeangliae) feeding ground in the Straits of Magellan, Chile: Journal of Cetacean Research and Management, v. 5, p. 203-208.

Goerlitz, D.S., Urban, J., Roja-Bracho, L., Belson, M., and Schaeff, C.M., 2003, Miochondrial DNA variation among Eastern North Pacific gray whales (Eschrichtius robustus) on winter breeding grounds in Baja California: Canadian Journal of Zoology, v. 81, p. 1965-1972.

Hayashi, R., 2012, Atlas of the barnacles on marine vertebrates in Japanese waters including taxonomic review of superfamily Coronuloidea (Cirripedia: Thoracica): Journal of the Marine Biological Association of the United Kingdom, v. 92, p. 107-127.

Hayashi, R., 2013, A checklist of turtle and whale barnacles (Cirripedia: Thoracica: Coronuloidea): Journal of the Marine Biological Association of the United Kingdom, v. 93, p. 143-182.

Hayashi, R., Chan, B.K.K., Simon-Blecher, N., Watanabe, H., Guy-Haim, T., Yonezawa, T., Levy, Y., Shuto, T., and Achituv, Y., 2013, Phylogenetic position and evolutionary history of the turtle and whale barnacles (Cirripedia: Balanomorpha: Coronuloidea): Molecular Phylogenetics and Evolution, v. 67, p. 9-14.

Hoffstetter, R., 1952, Les Mammifères Pleistocenes de la Republique de l'Equateur: Mémoires de la Société Géologique de France, nouv. sér., v. 66, p. 1391.

Hucke-Gaete, R., Haro, D., Torres-Florez, J.P., Montecinos, Y., Viddi, F., Bedrinana-Romano, L., Nery, M.F., and Ruiz, J., 2013, A historical feeding ground for humpback whales in the eastern South Pacific revisited: the case of northern Patagonia, Chile: Aquatic Conservation: Marine and Freshwater Ecosystems, v. 23, p. 858-867.

Hufthammer, A.K., Arntsen, L., Kitchener, A.C., and Buckley, M., 2018, Grey whale (Eschrichtius robustus) in Norwegian waters 2000 years ago: Palaeogeography, Palaeoclimatology, Palaeoecology, v. 495, p. 42-47.

IWC [International Whaling Commission], 2011, Report of the Scientific Committee, Annex F: Sub-Committee on Bowhead, Right and Gray Whales: Tromso, Norway, 30 May to June 112011.

Killingley, J.S., 1980, Migrations of California gray whales tracked by oxygen-18 variations in their epizoic barnacles: Science, v. 207, p. 759-760. 
Killingley, J.S., and Berger, W.H., 1979, Stable isotopes in a mollusk shell: detection of upwelling events: Science, v. 205, p. 186-188.

Killingley, J.S., and Lutcavage, M., 1983, Loggerhead turtle movements reconstructed from ${ }^{18} \mathrm{O}$ and ${ }^{13} \mathrm{C}$ profiles from commensal barnacle shells: Estuarine, Coastal, and Shelf Science, v. 16, p. 345-349.

Killingley, J.S., and Newman, W.A., 1982, ${ }^{18} \mathrm{O}$ fractionation in barnacle calcite: a barnacle paleotemperature equation: Journal of Marine Research, v. 40, p. 893-902.

Kimura, T., Hasegawa, Y., and Kohno, N., 2018, A new species of the genus Eschrichtius (Cetacea: Mysticeti) from the early Pleistocene of Japan: Paleontological Research, v. 22, p. 1-19.

Lamarck, J.B., 1818, Histoire Naturelle des Animaux sans Vertèbres 5: Paris, Verdière, Libraire, quai des Augustins, $612 \mathrm{p}$.

Leach, W.E., 1817, Distribution systématique de la classedes Cirripèdes: Journal de Physique de Chimie et d'Histoire Naturelle, v. 85, p. 67-69.

LeDuc, R.G., Weller, D.W., Hyde, J., Burden, A.M., Rosel, P.E., Brownell, R.L., Wursig, B., and Dizon, A.E., 2002, Genetic differences between western and eastern gray whales (Eschrichtius robustus): Journal of Cetacean Research and Management, v. 4, p. 1-5.

Lilljeborg W., 1861, Hvalben funna ijorden på Gräsön I Roslagen i Sverige: Forhandlinger ved de skandinaviske Naturforskeres, Kopenhagen, v. 8, p. 599-616.

Lindberg, D.L., 1991, Marine biotic interchange between the northern and southern hemispheres: Paleobiology, v. 17, p. 308-324.

Lindsey, E.L., and Lopez, E.X., 2015, Tanque Loma, a new late-Pleistocene megafaunal tar seep locality from southwest Ecuador: Journal of South American Earth Sciences, v. 57, p. 61-82.

Linnaeus, C., 1767, Systema Naturae per regna tria naturae, secundum Classes, Ordines, Genera, Species, cum characteribus, differentiis, synonymis, locis. Editio Duodecima, Reformata. Tom. I. Pars II: Holmiae, Laurentii Salvii, p. 533-1327.

Marchant, S., 1961, A photogeological analysis of the structure of the western Guayas Province, Ecuador: with discussion of the stratigraphy and Tablazo Formation, derived from surface mapping: Geological Society [London] Journal, v. 117, p. 215-233.

Martins, C.C.A., Morete, M.E., Engel, M.H., Freitas, A.C., Secchi, E.R., and Kina, P.G., 2000, Aspects of habitat use patterns of humpback whales in the Abrolhos Bank, Brazil, breeding ground: Memoirs of the Queensland Museum, v. 47, p. 563-570.

Mate, B.R., Ilyashenko, V.Y., Bradford, A.L., Vertyankin, V.V., Tsidulko, G.A., Rozhnov, V.V., and Irvine, L.M., 2015, Critically endangered western gray whales migrate to the eastern North Pacific: Biology Letters, v. 4, 20150071. https://doi.org/10.1098/rsbl.2015.0071.

Monroe, R., 1981, Studies in the Coronulidae (Cirripedia): shell morphology, growth, and function, and their bearing on subfamily classification: Memoirs of the Queensland Museum, v. 20, p. 237-251.

Newman, W.A., and Abbott, D.P., 1980, Cirripedia: the barnacles, in Morris, R.H., Abbot, D.P., and Haderlie, E.C., eds., Intertidal Invertebrates of California: Palo Alto, California, Stanford University Press, p. 504-535.

Newman, W.A., and Ross, A., 1976, Revision of the balanomorph barnacles; including a catalog of the species: San Diego Society of Natural History Memoir, v. 9, p. 1-108.

Noakes, S.E., Pyenson, N.D., and McFall, G., 2013, Late Pleistocene gray whales (Eschrictius robustus) offshore Georgia, U.S.A., and the antiquity of gray whale migration in the North Atlantic Ocean: Palaeogeography, Palaeoclimatology, Palaeoecology, v. 392, p. 502-509.

Nogata, Y., and Matsumura, K., 2005, Larval development and settlement of a whale barnacle: Biology Letters, v. 2, p. 92-93.

Pack, A.A., Herman, L.M., Craig, A.S., Spitz, S.S., Waterman, J.O., Hermn, E.Y.K., Deakos, M.H., Hakala, S., and Lowe, C., 2017, Habitat preferences by individual humpback whale mothers in the Hawaain breeding grounds vary with the age and size of their calves: Animal Behaviour, v. 133, p. 131-144.

Pilsbry, H.A., 1916, The sessile barnacles (Cirripedia) contained in the collections of the U.S. National Museum; including a monograph of the American species: United States National Museum Bulletin, v. 93, p. 1-366.

Pilsbry, H.A., and Olsson, A.A., 1941, A Pliocene fauna from Western Ecuador: Proceedings of the Academy of Natural Sciences of Philadelphia, v. 93, p. $1-80$.
Pyenson, N.D., and Lindberg, D.R., 2011, What happened to gray whales during the Pleistocene? The ecological impact of sea-level change on benthic feeding areas in the North Pacific Ocean: PLOS One, v. 6, e21295. https://doi.org/10.1371/journal.pone.0021295.

Ridgeway, S.H., Lindner, E., Mahoney, K.A., and Newman, W.A., 1997, Gray whale barnacles Cryptolepas rhachianecti infest white whales, Delphinapterus leucas, housed in San Diego Bay: Bulletin of Marine Science, v. 61, p. 377-385.

Rodrigues, A.S.L., Charpentier, A., Bernal-Casasola, D., Gardeisen, A., Nores, C., Millán, J.A.P., McGrath, K., and Speller, C.F., 2018, Forgotten Mediterranean calving grounds of grey and North Atlantic right whales: evidence from Roman archaeological records: Proceedings of the Royal Society B, 285, 20180961. https://doi.org/10.1098/rspb.2018.0961.

Sadler, J., Carre, M., Azzoug, M., Schauer, A.J., Ledesma, J., et al., 2012, Reconstructing past upwelling intensity and the seasonal dynamics of primary productivity along the Peruvian coastline from mollusk shell stable isotopes: Geochemistry, Geophysics, Geosystems, v. 13, Q01015. https:// doi.org/10.1029/2011GC003595.

Savoyat, E., 1971, Leyenda explicativa de la hoja de Montecristi, 1/100.000: Quito, Ecuador, Departamento de Investigacion Geologica, Ministero de Recursos Naturales y Turismo, Direccion General de Geologia y Minas, $6 \mathrm{p}$.

Scarff, J.E., 1986, Occurrence of the barnacles Coronula diadema, C. reginae, and Cetopirus complanatus (Cirripedia) on right whales: The Scientific Reports of the Whales Research Institute, v. 37, p. 129-153.

Seilacher, A., 2005, Whale barnacles: exaptational access to a forbidden paradise: Paleobiology, v. 31, p. 27-35.

Sheidat, M., Castro, C., Denkinger, J., Gonzalez, J., and Adelung, D., 2000, A breeding area for humpback whales (Megaptera novaeangliae) off Ecuador: Journal of Cetacean Research, v. 2, p. 165-171.

Sheppard, G., 1930, The geology of south western Ecuador: American Association of Petroleum Geologists Bulletin, v. 14, p. 263-309.

Slater, G.J., Goldbogen, J.A., and Pyenson, N.D., 2017, Independent evolution of baleen whale gigantism linked to Plio-Pleistocene ocean dynamics: Proceedings of the Royal Society B: Biological Sciences, v. 284, 20170546. https://doi.org/10.1098/rspb.2017.0546.

Swartz, S.L., 2018, Gray whale: Eschrictius robustus, in Würsig B., Thewissen, J.G.M., Kovacs, K., eds., Encyclopedia of Marine Mammals, $3^{\text {rd }}$ Edition: Cambridge, Massachusetts, Academic Press, p. 422-428.

Swartz, S.L., Taylor, B.L., and Rugh, D.J., 2006, Gray whale Eschrichtius robustus population and stock identity: Mammal Review, v. 36, p. 66-84.

Taylor, L.D., O’Dea, A., Bralower, T.J., and Finnegan, S., 2019, Isotopes from fossil coronulid barnacle shells record evidence of migration in multiple Pleistocene whale populations: Proceedings of the National Academy of Sciences, v. 116, 201808759. https://doi.org/10.1073/pnas.1808759116.

Tsai, C. H., Fordyce, R. E., Chang, C. H., and Lin, L. K., 2014, Quaternary fossil gray whales from Taiwan: Paleontological Research, v. 18, p. 82-93.

Tsai, C. H., and Boessenecker, R. W., 2015, An early Pleistocene gray whale (Cetacea: Eschrichtiidae) from the Rio Dell Formation of northern California: Journal of Paleontology, v. 89, p. 103-109.

Tsuchi, R., Shuto, T., Takayama, T., Fujiyoshi, A., Koizumi, I., Ibaraki, M., and Tirado, G.R., 1988, Fundamental data on Cenozoic biostratigraphy of the Pacific coast of Ecuador, in Tsuchi, R., ed., Trans-Pacific Correlation of Cenozoic Geohistory: Shizuoka, Japan, Reports of Andean Studies, Shizuoka University Special Volume 2, p. 23-43.

Whittaker, J.E., 1988, Benthic Cenozoic Foraminifera from Ecuador: Taxonomy and Distribution of Smaller Benthic Foraminifera from Coastal Ecuador (Late Oligocene-Late Pliocene): London, British Museum (Natural History), $194 \mathrm{p}$.

Zullo, V.A., 1961, A new whale barnacle from Late Pleistocene deposits at San Quintín Bay, Baja California: The Veliger, v. 4, p. 13-14.

Zullo, V.A., 1969, Thoracic Cirripedia of the San Diego Formation, San Diego County, California: Contributions in Sciences, v. 159, p. 1-25.

Accepted: 1 November 2021 